\title{
CUSSING AMONG THE KANKANAEY YOUTH
}

\author{
Ephraim Domingo ${ }^{1}$ \\ (Modern Educational Solutions Ltd.) \\ Analyn Caroy ${ }^{2}$ \\ (Saint Louis University) \\ Janice Carambas ${ }^{3}$ \\ (Pines City National High School) \\ Elaine Grace Dizon ${ }^{4}$ \\ (Saint Louis University) \\ Karyl Po-or \\ (Mt. Province State Polytechnic College)
}

\begin{abstract}
This paper explores the cuss words used by the Kankanaey young people of The Philippines, examines the reasons they use them and if these cuss words reflect their identity. It employs the qualitative approach and uses a semistructured interview. Most of the cuss words are terms that range from taboo topics such as the genitals, to inoffensive terms such as body parts, to incapacity, and to words borrowed and modified from English, as well as those invented. These cuss words are usually used to express emotions that range from light to strong ones such as anger, disappointment, fright, or surprise.
\end{abstract}

Keywords: Cuss words. Young people. Culture. Identity

Acknowledgment: This is an output for the course 'The Study of Language and Language Use' at Saint Louis University in Baguio City, The Philippines.

\section{RESUME}

Este artículo explora las malas palabras utilizadas por los jóvenes Kankanaey de Filipinas, examina las razones por las que las usan y si estas malas palabras reflejan su identidad. Emplea el enfoque cualitativo y utiliza una entrevista semiestructurada. La mayoría de las malas palabras son términos que van desde temas tabú como los genitales, hasta términos inofensivos como partes del cuerpo, incapacidad, y palabras prestadas y modificadas

${ }^{1}$ Ephraim V. Domingo has a master's degree in Language and Literature. He is an Assistant Language Teacher in Gunma, Japan and also an online English teacher.|2168856@slu.edu.ph

2 Analyn A. Caroy is a PhD in Language Education student of SLU. She is an assistant professor who teaches general education subjects. In 2018, she co-authored a Purposive Communication book published by Lorimar Publishing Inc. aacaroy@slu.edu.ph

${ }^{3}$ Janice R. Carambas is a PhD in Language Education student of SLU. She is a teacher at Pines City National High School in Baguio City, Philippines. She co-authored a book entitled "Ang Pagtuturo at Pagtataya ng Wika, Panitikan, at Kutura sa K to 12 Kurikulum". | hanisecruz@gmail.com

${ }^{4}$ Elaine Grace Dizon is an assistant professor at SLU where she teaches language, literature and art. She is a co-author of a published book entitled "Purposive Communication" by Lorimar Publishing Inc. She is a PhD candidate in the program Doctor of Philosophy in Language Education. | elainegracejdizon@gmail.com

${ }^{5}$ Karyl A. Po-or is an Assistant Professor at the Mountain Province State Polytechnic College, Philippines. She is a PhD Language Education student of SLU 
del inglés, así como las inventadas. Estas malas palabras generalmente se usan para expresar emociones que van desde ligeras a fuertes como la ira, la decepción, el miedo o la sorpresa.

Palabras clave: Malas palabras. Jóvenes. Cultura. Identidad.

Reconocimiento: Esta es una salida para el curso "El estudio del lenguaje y el uso del lenguaje" en la Universidad de Saint Louis en la ciudad de Baguio, Filipinas.

Recebido em: maio 2018

Aceito em: dezembro 2019

DOI: $\underline{10.26512 / \text { les.v20i2.24831 }}$

\section{INTRODUCTION}

\section{BACKGROUND}

Despite being underexplored in research, pragmatics as a field of study stands across multiple fields of studies that include sociolinguistics, semantics, and studies on impoliteness, in which the use of cuss words is a part. Cusses, or swear words, are words or phrases in any language that are used to insult someone by using comparison to an animal "in regard to stupidity, loveless sex, and lack of spirit or reason, or to a body part or product...; or to a socially despised, feared, or "different" group" (HENRY, 2018, p. 91). Unlike curses that involve evil calls, cusses are usually “dirty" words that we use when we express strong feelings like hate, pain, and frustration.

Cussing has a very long history. Long ago people did not put bad words into writing (RAHMAN, 2017). Cussing or swearing was used sparingly and was not common until the Middle Ages when it became usual; however, there were no discrimination in gender and age (MONTAGU, 2001). In fact, the first record of the use of cuss words dates back to the Ancient Egypt when cussing was done in the name of the gods and was not at that time associated with bad language, and was not a taboo (LJUNG, 2010). Today, although cussing has become common and popular, it is socially condemned (RAHMAN, 2017) and considered obscene because people view it in the contemporary times as putting the name of god in vain. This makes cussing a very interesting topic because it involves both emotional and linguistic expressions (SCHIPPERS, 2013).

Swearing among adults has been a subject of research for the last 30 years (JAY; JAY, 2013). Those studies involving how adults use the language (JAY, 1992; MEHL; PENNEBAKER, 2003) show that taboo words such as swearing, cursing or expletives come from different sources and semantic 
domains, including sex, body parts, and religious terms (HENRY, 2018; JAY; JAY, 2013). This further demonstrates their knowledge of taboo words as they use them either connotatively or denotatively and still gets the message across (JAY, 2000).

Among children, adult-like swearing emerges nowadays. In fact, even before entering school children have already had bits of it. This is one proof that swearing habits has been changing (JAY; JAY, 2013). This can be attributed to the popularity and easy access to pop media such as songs, TV programs especially soap operas and talk shows, and movies. Because of this, it is almost impossible to avoid not being exposed to cuss words (SHARMA, 2018) especially among children.

There could be too many words or phrases in every language that may or may not be considered cuss. This decision on whether or not a word is considered cuss lies solely on the native speakers of a certain language. However, it can be decided by looking into the written part of any language because it is in textbooks, dictionaries and other print media where it is decided which part is good or bad in verbal language (SHARMA, 2018).

Despite the obvious "badness" of cuss words in every language, they are still considered important for every society that uses them. After all, language is a part of our culture (GEERTZ, 1973; GUMPERZ, 1982; HAKUTA, 1996; LEVINE, 1984; ROMAINE, 2000; SALZMANN, 1993) and it might comprise memories and strong emotions from the home environment (ANDREWS, 2010). Our language also reflects both the thoughts of its users and their relationship with nature and society (SHARMA, 2018). Therefore, cuss words, being an integral part of any language, demonstrate the "linguistic decadence" of the social group that uses it (SHARMA, 2018, p. 293).

There are several studies on the use of cuss words. One study focused on the frequency of use of cuss words in the English language and its implications (BRAM, 2018) and another emphasized on young learners and found out that anger was the number one reason for using cuss words (SUGANOBNICOLAU, 2016). The possibility of including cuss words in the curriculum in an English as a Second Language set up was also explored (FINN, 2007).

While some delved into the frequency of using cuss words, others were interested in studying how exactly people cuss. The body of literature of using cuss words would normally point to teenagers and old people in the Western culture, while very few involve Asian culture because it is deemed to be very conservative (RAHMAN, 2017). Among the Japanese people, very few cuss words are available in their language because their culture demands caution; hence, they tend to be very careful with their words 
(MAYNARD, 2002). On the contrary, in the European and Western cultures, people who use cuss words are rarely reprimanded (JAY; JANSHEWITZ, 2008).

Some researches argue that very little is known about the use of swear words and that few relevant studies have been made and some researches is not primarily on sociolinguistic variables (GATI, 2014; XIAO, 2004). It is very important to see this kind of researches in a public setting as the correct physical and social setting for the use of swear words like what sociolinguistics is reflecting to (JAY, 2009). There are also few researches on cuss words and swear words regarding cross-cultural phenomenon and if it is passed on from one generation to the other (KHALID et al., 2016). There is a possibility that they inherited this habit from their parents, or that the society is the main reason behind such kind of behaviors (PATRICELLI, 2015).

The Kankanaey language, spoken by more than 260,000 people (2005 UNSD) in the Cordillera Administrative Region in north-central Philippines is, like many others, one that is rich in cuss words that are used in different contexts, purposes, speakers, and interlocutors. Spoken mainly in Benguet, southwest Ifugao, southwest Mt. Province and parts of Ilocos region, it is considered "developing" (ETHNOLOGUE, n.d.a). That means that it is "in vigorous use, with literature in a standardized form being used by some though this is not yet widespread or sustainable" (ETHNOLOGUE, n.d.b).

This study aims to identify the cuss words used in the Kankanaey language as used by the youth. It also aims to discover when and in what situations these cuss words are used. Furthermore, it attempts to explore the reasons these cuss words are used, as well as their communicative functions. Finally, it aims to analyze the social impacts of using cuss words and whether or not it affects the expression of identity among its speakers.

Specifically, it aims to answer these research questions:

1. What are the usual cuss words that the Kankanaey youth use in their daily conversation?

2. Do these cuss words reflect the culture they are in now?

3. How do culture and the society affect the use of cuss words on the individual level?

Speaking cuss words or more commonly known as bad words brings a bad image to the community speaking the language. There could be an unfavorable impact if native speakers use cuss words all the time, most especially if it used for superficial reasons. If speakers are aware of the cuss words that they use and the impact they may bring, there is a possibility that they would speak less cuss words. Generally, using cuss words is frowned upon and may be considered taboo; hence, knowing and studying these cuss words will provide explanations as to why such cuss words are used and in which 
contexts. Data from this study can be applied in sociolinguistic issues, as well as in certain academic explorations.

\section{Methodology}

This study uses the descriptive qualitative design that is used to explore the comprehensive summarization of daily expressions and specific events experienced by a person or groups of people (LAMBERT; LAMBERT, 2012). For several reasons, this design is in accordance with the objectives of this study. First, it identifies and describes the different cuss words used in daily speech, as well as the various reasons for their utility. Second, this paper interprets the data based on the recorded cuss words and claims on the use of cuss words by the participants.

Data in this research are the cuss words used, perceptions of cuss words, and their cultural implications. The participants are thirteen (13) randomly-selected Kankanaey-speaking youth enrolled in a university in Baguio City, Philippines. Their ethnicity as Kankanaey was confirmed in the course of the interview. Hence, for the purpose of this study, the respondents are key-informants. Key-informant interview is an in-depth interview whereby selected human subjects have first-hand knowledge of a certain topic (USAID, 1996).

Prior to the collection of data, the participants were oriented of the purpose of the study. Verbal consent was given by each respondent as confirmation for their participation in the interview. The researchers personally administered the data gathering procedure which involves a recorded interview following a self-prepared semi-structured questionnaire to meet the identified objectives of this study. Semi-structured interview allows for structure and ease of response analysis between participants and is used to explore issues or phenomena that may be delicate to the respondents and permits possible probing and elaborations to completely understand responses (BURNBALL; WHITE, 1994; LANDRIDGE; JOHNSON, 2009). Also, it permits flexibility in the response and questions asked. The first part asks each respondent's demographic profile in terms of age, ethnicity, gender, languages spoken, and place of birth.

The second part identifies the cuss words the respondents use, the influencers behind their learning of cuss words, their personal reasons for using cuss words, their moral perception of the use cuss words, and the relationship between the use of cuss words and their ethnic identity. In getting enough and clear data for the research analyses, probing was done. Transcription of the interview followed. 
Data analysis consists of data recording, transcription, and interpretation. Along with the data collection, the researchers transcribed all the utterances produced by the participants. When it was found that the responses received had reached saturation, the interview ceased to continue with other possible respondents. Data saturation aims to process raw data obtained in order to be analyzed. The process occurs when there is no new data, and the data gathered can no longer generate new codes or themes (GUEST et al., 2016). When there is no new theme, then there is no new data and no new coding (O'REILY; PARKER, 2012). Thus, when this point has been reached, one has reached data saturation regardless of population size (BURMESTER; AITKEN, 2012).

\section{RESUltS AND DisCUSSION}

Cuss words are usually uttered due to burst of strong feelings such as frustration, anger and even happiness by people who belong to a particular society. In order to understand the context behind cuss words, this part of the research explains the results and interpretations of the answers from the interview done for this purpose. The interview questions were based on the three main problems namely: (1) What are the usual cuss words that the Kankanaey speaking youth use in their daily conversations? (2) Do these cuss words reflect the culture they are in now? and (3) How do culture and the society affect the use of cuss words per individual? The respondents were students from a university in Baguio City where a large number of Kankanaey people live and/or where many Kankanaey students learn.

From the answers given, the $3 C^{\prime}$ 's of Kankanaey language in the context of cuss words is formulated to reflect the main themes in this research. These are: cuss words, culture, and cases. Cuss words are uttered in different cases that eventually affect culture and vice versa. These themes generate the answers to the research questions.

\subsection{Cuss Words}

Language is an important aspect of one's culture and a form of communication of one's ideas, emotions and state of mind (JAY, 2009). It is unique across cultures with varying degrees of expression in communication that may be central to one culture but not the other. One aspect that seems to be static across culture barriers is that each language has its own form of profanity or taboo words that express emotions. Taboo words or cuss words are a profane or obscene oath or word that is a remark of a certain feeling. One factor to consider when a person is using cuss words is the context of the conversation 
between the speaker and listener. The social setting and the topic of conversation are a great factor of using cuss words (GATI, 2014). The cuss words might be also affected by the languages spoken by a person.

A number of cuss words were reported to have been in use among the participants of this study. These are grouped into four major categories, namely: Sexual/Human Genital Terms; Body Parts/ Wastes; Incapability Terms; and Borrowed and Invented Terms. The table below lists down the cuss words used by the Kankanaey youth with a direct/literal translation of each one of them.

Table 1 - Categories of cuss words in Kankanaey

\begin{tabular}{|c|c|c|c|c|c|c|c|}
\hline \multicolumn{2}{|c|}{$\begin{array}{l}\text { Category } 1 . \\
\text { Sexual/Human Genital } \\
\text { Terms }\end{array}$} & \multicolumn{2}{|c|}{$\begin{array}{l}\text { Category 2: } \\
\text { Body Parts/Body } \\
\text { Wastes }\end{array}$} & \multicolumn{2}{|c|}{$\begin{array}{l}\text { Category 3: } \\
\text { Incapability Terms }\end{array}$} & \multicolumn{2}{|c|}{$\begin{array}{l}\text { Category 4: Borrowed and } \\
\text { Invented Terms }\end{array}$} \\
\hline Kankanaey & English & Kankanaey & English & Kankanaey & English & Kankanaey & English \\
\hline $\begin{array}{l}\text { ukinnana } \\
\text { ukkinnam } \\
\text { kin-inam } \\
\text { ukininam } \\
\text { sipit-inam } \\
\text { idap } \\
\text { fotlim }\end{array}$ & $\begin{array}{l}\text { (your/ } \\
\text { his/her/ } \\
\text { their) } \\
\text { mother's } \\
\text { sex } \\
\text { organ }\end{array}$ & $\begin{array}{l}\text { ingam } \\
\text { matam } \\
\text { furangag } \\
\text { fulangagmu } \\
\text { fulingig }\end{array}$ & $\begin{array}{l}\text { (your) } \\
\text { ears } \\
\text { eyes } \\
\text { butt } \\
\text { your } \\
\text { butt } \\
\text { butt }\end{array}$ & $\begin{array}{l}\text { tabbed } \\
\text { tabfed } \\
\text { luwerk }\end{array}$ & $\begin{array}{l}\text { stupid } \\
\text { you're } \\
\text { deaf }\end{array}$ & $\begin{array}{l}\text { masemo } \\
\text { gaddimet }\end{array}$ & $\begin{array}{l}\text { That's what } \\
\text { you get. } \\
\text { God damn it! }\end{array}$ \\
\hline & & & & & & $\begin{array}{l}\text { shadap, } \\
\text { wekwek } \\
\text { buldang } \\
\text { burshingaw }\end{array}$ & Shut up! \\
\hline $\begin{array}{l}\text { lokdit } \\
\text { loksit } \\
\text { lokchit } \\
\text { tilim }\end{array}$ & $\begin{array}{l}\text { male sex } \\
\text { organs }\end{array}$ & $\begin{array}{l}\text { taim } \\
\text { bulsit } \\
\text { borhet } \\
\text { borshet }\end{array}$ & $\begin{array}{l}\text { Your } \\
\text { crap! } \\
\text { (human } \\
\text { waste) } \\
\text { Bullshit! } \\
\text { (animal } \\
\text { waste) }\end{array}$ & & & & \\
\hline $\begin{array}{l}\text { sipit } \\
\text { lawit }\end{array}$ & $\begin{array}{l}\text { sex } \\
\text { organs }\end{array}$ & & & & & & \\
\hline
\end{tabular}




\subsubsection{Category 1. Sexual Organs/Human Genital Terms}

Most of the cuss words being spoken by the participants fall under the category of 'sexual' or 'genital' terms. The participants commonly utter "ukinnana”, "ukkinnam", "kin-inam”, "ukininam”, "sipit-inam", "fotlim" and "idap" which all mean the same thing as pertaining to one's mother's sex organ. These words are addressed to everyone regardless of their gender. While each of these cuss words seems to be directed to the interlocutor's or the third person's mother, it is not actually the case when they are uttered. That is, the speaker does not necessarily address it to one's mother but rather as only an expression used in expressing certain emotions.

Other words that belong under this category are "lokdit", "loksit", "lokchit", and "tilim" which all refer to the male sex organs; and "sipit" and "lawit" still pertaining to sex organs in general. Unlike those that pertain to one's mother's genitals, these cuss words are directed to male interlocutors or third persons, therefore they are not typically used when talking to or about female individuals.

Most of the time, these cuss words are uttered to express negative strong emotions such as anger, disappointment, or fear. Interestingly, there are instances, too, when they are uttered casually as in meeting a friend, or in expressing positive emotions like happiness or surprise. The use of words related to human sexuality is a critical feature of emotional language in general and of cursing in particular because sexuality is one of the most tabooed part of human lives (JAY, n.d.). After all, the language of sexuality is closely linked to one's emotional life, sexual orientation, and cursing behaviors or style.

\subsubsection{Category 2: Body Parts/Body Wastes}

Some of the cuss words used to curse at a person pertain to the body parts, some of which are inoffensive in nature. These are "ingam” (your ears), "matam” (your eyes), "furangag/ fulangag mu/ fulingig" (your butt). These words may not be semantically related to any offensive or taboo part of the body but are used nonetheless to express less strong feelings such as surprise, disbelief, or disappointment. These words, therefore, do not usually cause offense when uttered, but are enough to signal the speaker's feelings at the time of utterance.

In addition, words pertaining to human or animal wastes such as "taim” (your crap), "bulsit / borhet / borshet" (variations of 'bullshit') are also often used. The use of such cuss words connotes a stronger feeling than that of the body parts, hence, may cause offense to some to whom they are directed. 


\subsubsection{Category 3: Incapability Terms}

Cuss words in this category are those that describe mental and physiological weaknesses of a person not necessarily describing the one to whom the cuss words are directed to. Under this category are "tabbed / tabfed" (stupid), and "luwerk" (you're deaf).

The words "tabbed / tabfed" are used almost exclusively to express one's disappointment over a bad decision, its consequences, a failed or funny act, or a bad remark. On the other hand, "luwerk" is uttered usually when the interlocutor or a third person seems to be having difficulties hearing, or when one's advice is not followed.

\subsubsection{Category 4: Borrowed and Invented Terms}

Some cuss words or phrases are borrowed from English cuss words and modified to fit the phonological aspects of Kankanaey while others are invented. Among the borrowed cuss phrases are: "gaddimet" (god damn it), and "shadap" (shut up). These words are used almost in the same situation or circumstance as when their English counterparts are uttered, that is, to express strong feelings and to make some stop from talking respectively. Other cuss words like "masemo", "wekwek", "buldang”, and "burshingaw" do not have any literal translation, nor do they pertain to any object or concept. The invention of such words, as perceived by the participants, was solely for the purpose of cussing.

The use of cuss words among the Kankanaey youth is claimed to be an influence they get from the community, their family, and their friends. Typically, as children they heard the words from their environment until they themselves started using them. One of the participants said, "I usually hear them saying these bad words...I learned [the cuss words] from my family, friends, teachers and other people...I heard it from the community."

It is also worth noting that they were not explicitly taught those cuss words. One participant said, "Nobody taught me how to curse." This shows that most cuss words are acquired or learned unconsciously or unintentionally. Another claimed, "I was not taught. I only heard it from my playmates," and one said, "Most of the time, I keep on learning from my friends." This indicates that individuals easily learn swear words from other people and that others are influential in making others come to learn how to swear. Such exposure to a person who swears makes it for one to easily learn how to utter swear or cuss words. It appears that people have stronger and more powerful influence for youths to learn how to swear (NICOLAU, 2016). Furthermore, young learners respond faster to human 
impetuses, that is, they personally communicate, share ideas and listen from/to each other. This is the reason learning the cuss words at a young age is inevitable.

\subsection{Cases}

The second theme - cases - discusses when and where the respondents use and learned cuss words. It is natural for people to curse because of many reasons. There are also a number of advantages and disadvantages of cursing. One reason people curse is for them to express strong emotions and by doing so, it eases the pain or frustration, or emphasizes feelings of joy or surprise. The statements below from the respondents are the evidence why cuss words are used.

I used cuss words especially when I am angry or happy. For example, if I pass the quiz I usually say, “Ay, shet, pimasaak!” (Oy, sh*t, I passed!) [I am] excited like that.

I usually utter it when I am happy, angry, or shocked. Everyone actually. I use it to express my emotions.

As in the first statement, the respondent utters cuss words as a mere expression of surprise or joy certain simple unexpected situations like passing a quiz. This does not necessarily mean that the utterance is done out of the gravity of the emotion felt, but rather it shows that cuss words may be expressed casually as if it is part of human nature.

Furthermore, other feelings also call for the use of cuss words. This is due to several reasons but it is believed that cursing in the form of interjection due to exhaustion, anger, frustration, surprise or even happiness eases the negative feelings and reinforces the positive feelings of the speaker (MOKBEL, 2013).

Because of these situations, cursing is deemed to be a natural part of human nature. But in reality, curses are learned by a person. There are many assumptions about the use of swear words including that of media which plays an important role in exposing children to cuss words. The statement below shows how the participants learned cuss words.

[My] environment (Peers, Community) [taught me to use cuss word]. I usually hear them saying these bad words until such time I am already using it also.

No one taught me, but I have been learning from my community. 
The words 'environment' and 'community' highlight the factors affecting the use of cuss words of the respondents based on different situations. The use of cuss words and how they are learned are influenced by the environment or the society where a person lives (TAJOLOSA, 2012). The environment has a big impact on the respondents' language use. Besides the environment, the people around the respondents have a great impact, too, in their use of cuss words. People usually learn through mimicking and eventually it becomes part of their lives. We need also to consider the relationship a person has with the people using cuss words because this can have a significant impact on what is considered as impolite or rude (LOCHER; WATTS, 2005).

\subsection{Culture}

Culture is the primary part that expresses to what society, interests, and organization a person places himself in (JAY, 2009). It can comprise of education, music, arts, morals and most significantly language (NOCELLA, 2013).

One area of language that culture has a big impact on is his profanity. Profanity, also called curse words, is a subgroup of language that is said to be resilient, offensive and, in general bad. However, these words can still be considered as a part of an individual's usual expression and are deemed okay to say or play with under some instances. The allowed use of profanity emanates from culture since culture gives meaning to profanity. Some behaviors and language that are accepted and common for one culture are considered as so offensive and rude for another culture, most especially that culture gives varied meanings on what is social norms and what is not.

However, in the case of this study, the participants differ in their answers to the questions "Do these cuss words reflect the culture they are in now - their being a Kankanaey?" Some of them gave a negative answer as reflected in the following statements:

No, kasi lahat naman nagmumura, so it doesn't specify your uniqueness.

No, because I think the use of cuss words is a common thing; it only differ in terms of the dialect used. 
No, it does not contribute at all because there are a lot of unique identities of Kankanaey and cussing is not one of them.

No, because we are following the norm 'inayan' which is why it does not contribute to anything.

As reflected in the preceding statements from the participants, the use of cuss words do not necessarily contribute or strengthen their identity as Kankanaey. They believe that each language and society for the matter has cuss words. Therefore, cuss word in Kankanaey language and communities should be treated like those of any other language — ordinary and normal. Moreover, they emphasize the 'inayan', a word that encapsulates the norms and values of the Kankanaey communities. Uttering cuss words for the Kankanaey is "inayan", a part of their culture that embodies all the warnings to individuals to shun away from doing evil or bad deeds, uttering bad or cuss words.

In the Kankanaey language, "inayan" is a lexicon whose meaning is to stop, prevent or restrain a person from doing something bad to others. It also refers to the fear of a Supreme Deity whom they called Kabunian (god) who warns one from doing harmful things to the others (LAGMAY, 2012) and a community value that is similar to karma or the concept of "you reap what you sow". This value cautions a person from doing or violating cultural norms or taboos. Furthermore, 'inayan' among Igorots is the summary of the Ten Commandments (LEYALEY, 2016). Because of 'inayan', one has to avoid taking risks, cussing, and engaging in some bad or unwanted cussing encounters with the others.

If the word is evoked, the speaker usually reminds their interlocutor of their values and the norms that have long been established in their society. At the same time, it calls for some sort of guidance to do the right thing and wish that it be done. Finally, it is believed that there are better features of the Kankanaey society that fully speak of their traditions and values than the cuss words they use.

On the other hand, some students gave a positive and contradicting answer as shown in the following statements:

Yes, usually. It is not just the cuss words themselves, but how it is uniquely said - the tones, intonations, and other aspects that build up the word that can reflect the culture and identity of a certain person/group.

Cursing does really contribute to my identity as a Kankanaey internally because (I think) whenever I curse, I pronounce it the way it is (which is harsh). 
Yes because you will know the ethnicity of the person when you hear their accents and how they say the cuss words or there is a certain cuss that is only in their place.

Yes, because it is our language. No matter where you go, these words will be used by Kankanaey.

These statements underline the uniqueness of the Kankanaey cuss words in terms of their intonation, pronunciation, and vocabulary. To them, those cuss words they use reflect who they are and strengthen their identity especially when they are outside their own communities. Cuss words become a tool for identifying who in a crowd is a Kankanaey by simply fully examining how such words are uttered and used.

When it comes to the question on whether or not cussing is bad, the majority of the participants agree on the affirmative. Culture and society have an impact on the use of cuss words by the people and therefore are indicative of the reasons why the participants look at cussing as bad. This is reflected on the following statements:

It is bad when you hurt someone because it is inappropriate; it gives out a negative image when you hurt someone's feelings, and it makes your image bad.

They are bad. It stains the image of the Igorot people because of the 'inayan'value. And I think cussing is one of the 'inayan'.

This goes back again to the concept of 'inayan' in which it is really bad to utter cuss words for it will hurt someone else's feelings. Further, going against this concept will mean something bad or the bad things you have said or done will go back to you. It is further believed that the "inayan" system of the Kankanaey reflects the positive value of their culture which is against negativism like cuss words. This is truly answered by the statement mentioned by the participant which emphasized on the image of the Igorot people of the value "inayan".

With the statements mentioned above, swearing is a cultural thing (KROULEK, 2013) but it is also believed that it stains the values and norms in a society. Most languages have a set of words that one really should not say, unless you really intend to cause trouble, as believed by the participants when they 
said it hurts someone's feelings. However, it all boils down to the idea that different cultures have different values and taboos, and that means they swear differently also (KROULEK, 2013).

\section{Conclusion}

Like in any socio-linguistic group and language, Kankanaey has a source of cuss words that are uttered in different contexts and purposes and were learned from different cultures. General cuss words ranges from sexual terms, especially those that pertain to the mother's genitals, and other words related to both man and woman's genitalia; to inoffensive body parts such as the eyes and ears; to words pertaining to physical or mental incapacity; to words borrowed and modified from the English language; and other words made up by the society. These cuss words are typically uttered to express emotions that range from the light ones such as disbelief and happiness to extreme feelings like disappointment, fright, and anger. Nevertheless, expressing oneself through these cuss words are believed to be not reflected of one's culture as this same culture also follows strong norms, morals, and values that have helped shape their communities and identity as Kankanaey. Their strong belief and practice of the "inayan" concept has been the foundation of their moral values that reflect the concept of humility and all the virtues and morals of Kankanaey people. It is based on human conscience of doing good for other people. This is their unique guide in not uttering cuss words. In addition, cuss words add to their identity as a people because it serves as a tool in identifying who belongs and who doesn't to their group.

It is recommended that further studies be explored involving participants of a different age groups such as adults and the elderly. Moreover, an in-depth exploration on the cuss words' effects on one's identity and culture is also recommended. Finally, a similar study of the other Cordilleran languages may also be undertaken; results of which may further be compared with those of this study.

\section{REFERENCES}

ANDREWS, M. What about linguistic identity? Journal of Language and Literacy Education [Online], V. 6, n. 2, p. 85-102, 2010.

BRAM, B. Swear words and their implication for English language learning-teaching. LLT Journal: A Journal of Language and Language Teaching, n. 21, p. 43-49, 2018.

BURMEISTER, E.; AITKEN, L. M. Sample size: How many is enough? Australian Critical Care, n. 25, p. 271-274, 2012.

ETHNOLOGUE. Kankanaey. Retrieved from https://www.ethnologue.com/language/kne. n.d.a. 
ETHNOLOGUE. Language status. Retrieved from https://www.ethnologue.com/about/language-status. n.d.b.

FINN, E. Swearing: The good, the bad, the ugly. ORTESOL Journal, n. 34, p. 17-26, 2007.

GATI, P. The use of swear words by women: a study of single sex and mix sex conversations. Thesis Unpublished, Halmstad University, Halmstad, Sweden, 2014. p. 61-90.

GEERTZ, C. The interpretation of cultures. New York: Basic Books, 1973.

GUEST, G.; BUNCE, A.; JOHNSON, L. How many interviews are enough? An experiment with data saturation and variability. Field Methods, 18(1), 59-82, 2006.

GUMPERZ, J. Discourse strategies. Cambridge: Cambridge University Press, 1982.

HAKUTA, K. Mirror of language: the debate on bilingualism. New York: Basic Books, 1996.

HENRY, D. On cursing. The Massachusetts Review, Volume 59, Number 1, 2018, 91-96, 2018.

JANSCHEWITZ, K. Taboo, emotionally valenced, and emotionally neutral word norms. Behavior research methods, v. 40, n. 4, p. 1065-1074, 2008.

JAY, K.; JAY, T. A Child's Garden of Curses: A Gender, Historical, and Age-Related Evaluation of the Taboo Lexicon. The American Journal of Psychology, v. 126, n. 4, p. 459-475, 2013.

JAY, T. Cursing in America. Philadelphia, PA: John Benjamins, 1992.

JAY, T. The utility and ubiquity of taboo words. Perspectives on Psychological Science, v. 4, n. 2, p. 153-161, 2009.

JAY, T. Why We Curse A Neuro-Psycho-Social Theory Of Speech. John Benjamins Publishing Company: Philadelphia/Amsterdam, n.d.

JAY, T.; JANSCHEWITZ, K. The science of swearing. The Observer, v. 25, p. 5-6, 2012.

JAY, T. B. Why we curse: A neuro-psycho-social theory of speech. Philadelphia, PA: John Benjamins, 2000.

JAY, T.; JANSCHEWITZ, K. The pragmatics of swearing. Journal of Politeness Research. Language, Behaviour, Culture, v. 4, n. 2, p. 267-288, 2008.

KROULEK, A. Swearing: It's a Cultural Thing. 2013. Retrieved from https://www.kinternational.com/blog/swearing-its-a-cultural-thing/.

LAGMAY, H. The Inayan Concept Among Igorot. Retrieved from http://livewith prettyheart.blogspot.com. August 12, 2013, 2012.

LAMBERT, V.; LAMBERT, C. Qualitative descriptive research: An acceptable design. Pacific Rim International Journal, 2012.

LEVINE, R. Culture theory. In: SHWEDER, R.; LEVINE, R. (ed.), Culture theory: Essays in mind, self, and emotion. Cambridge: Cambridge University Press, 1984. p. 67-87.

LEYALEY, R. Iyanan: The tenet for peace among the Igorot. International Journal of Advanced Research in Management and Social Sciences, v. 5, n. 2, February 2016.

LJUNG, M. Swearing: A cross-cultural linguistic study, 2010. 
MAYNARD, S. Japanese communication: Language and thought in context. Honolulu, Hawaii: Univ. of Hawaii Press, 2002.

MEHL, M.; PENNEBAKER, J. The sounds of social life: A psychometric analysis of student's daily social environments and natural conversations. Journal of Personality and Social Psychology, n. 84, p. 857-870, 2003.

MOKBEL, J. Profanity's relation to personality and impulsivity (Master's thesis, University of Central Florida, Florida). Retrieved from http://stars. library.ucf.edu/cgi/viewcontent.cgi ?

article=2438\&context=honorstheses19 90-2015, 2013.

MONTAGU, A. The anatomy of swearing. Philadelphia, PA: University of Pennsylvania Press, 2001.

NICOLAU, M. Swear words among young learners: A case study of the elementary students. Retrieved from https:// ojs.atmajaya.ac.id/index.php/ijelt/article/view/825/665, 2016.

NOCELLA, V. Culture and Profanity. Retrieved from

https://scienceleadership.org/blog/culture_and_profanity, 2013.

O'REILLY, M.; PARKER, N. Unsatisfactory saturation: A critical exploration of the notion of saturated sample sizes in qualitative research. Qualitative Research Journal, p. 1-8, 2012.

RAHMAN, S. Swearing: A cross cultural study. Asian and European Languages, 2017.

ROMAINE, S. Language in society: An introduction to sociolinguistics. $2^{\text {nd }}$ ed. New York: Oxford, 2000.

SALZMANN, Z. Language, culture, and society. Boulder, Colorado: Westview Press, 1993.

SHARMA, M. Why the hell are cuss words not included in teaching of Portuguese as foreign language?!. Matraga rio de janeiro, v.25, n.44, 292-317, 292-317, 2018.

SUGANOB-NICOLAU, M. Swear words among young learners: A case study of the elementary students. Indonesian Journal of English Language Teaching, 11(2), 117-132, 2016.

TAJOLOSA, T. D. Conversational topic preferences, taboo words and euphemisms: The case of Philippine male and female university students. Philippine ESL Journal, 76-95, 2012. 